\title{
62. SYNTHESIS OF ORGANIC GEOCHEMICAL STUDIES, DEEP SEA DRILLING PROJECT LEG 93, NORTH AMERICAN CONTINENTAL MARGIN1
}

\author{
Philip A. Meyers, The University of Michigan ${ }^{2}$
}

\begin{abstract}
The results of organic geochemical studies of samples from Site 603 on the outer Hatteras Rise and from Sites 604 and 605 on the New Jersey continental slope are reviewed and integrated with lithostratigraphic information from those locations. Although most of the sediments and rocks encountered at all three sites contain little organic carbon, "black shales" enriched in organic matter were found in Cretaceous strata obtained from Hole 603B. These rocks exist as claystones in the Aptian to Turonian Hatteras Formation and as marlstones in the Neocomian Blake-Bahama Formation. Terrigenous organic matter predominates in these deposits, except in Cenomanian and Valanginian rocks, where marine material becomes dominant. Organic carbon concentrations in Cenomanian black claystones are higher than any previously reported from the western North Atlantic, but lower than the concentrations found in the eastern North Atlantic. Black shales at Site 603 appear to result from downslope transport and rapid reburial of coastal and ocean margin sediments by turbidity flows. Deep-basin anoxia is not a major factor. At Site 605, a well-defined Cretaceous/Tertiary boundary was obtained, and terrigenous components of the organic matter diminished in sediments deposited above this boundary. Organic matter in the sediments from all locations is thermally immature.
\end{abstract}

\section{INTRODUCTION}

A variety of processes influence the organic matter content of marine sediments. Concentrations are affected by the rates of supply of land-derived and marine matter, the rate of sediment accumulation, and the rate of post-depositional degradation of organic substances. The character of organic matter reflects biotic sources, transport routes, degree of preservation, and extent of geothermal alteration. Study of the organic matter present in older marine sediments can provide information from which a number of paleoceanographic factors can be inferred.

During DSDP Leg 93, samples were collected from Sites 603,604 , and 605 for postcruise organic geochemical study. Selection of the samples was based upon the specific requirements of each group, coordinated when possible with the needs of other groups. In this way, several different types of analyses were performed on related samples and investigators were not limited to randomly selected samples for their studies. One of the goals of this overview of the 14 studies of organic matter in Leg 93 samples is to integrate their results, especially those from samples that are closely spaced or are lithostratigraphically related. Nonetheless, it is important to point out that few investigators actually shared samples, and therefore integration of data has its limits.

The overview is divided into two parts, one dealing with the outer Hatteras Rise (Site 603) and the other with the upper New Jersey Rise (Sites 604 and 605). Each part is further subdivided into the respective lithostratigraphic units present in each setting.

\footnotetext{
${ }^{1}$ van Hinte, J. E., Wise, S. W., Jr., et al., Init. Repts. DSDP, 93: Washington (U.S. Govt, Printing Office).

2 Address: Oceanography Program, Department of Atmospheric and Oceanic Science, The University of Michigan, Ann Arbor, MI 48109-2143.
}

\section{SITE 603: OUTER HATTERAS RISE}

Site 603 is located in $4434 \mathrm{~m}$ of water on the lower continental rise off North Carolina (Fig. 1). A nearly continuous record of sediment accumulation from Pleistocene to Berriasian times was recovered from the three holes cored on Leg 93, augmented by the holes cored at this site on Leg 95. The lithostratigraphic units encountered at Site 603 are shown in Figure 2 and are fully described in the Site 603 chapter (this volume). These units correspond to five of the six widespread Mesozoic-Cenozoic sedimentary formations identified in the western North Atlantic by Jansa et al. (1979). The sixth formation was probably present at Site 603, but failure and resulting loss of the drill string terminated drilling before the entire sedimentary sequence had been penetrated. In Table 1, the results of organic geochemical analyses of samples from the five formations cored at Site 603 are summarized.

\section{Unit I: Blake Ridge Formation (Eocene to Pleistocene)}

Organic carbon concentrations are low throughout Unit I and bear some relationship to the lithologic character of the four subunits, although often subtly. The upper three subunits, all containing microfossils, average $0.32,0.28$, and $0.34 \%$ organic carbon, whereas the lowermost subunit, barren of microfossils, is virtually devoid of organic matter as well (Meyers, this volume).

The decrease in both organic carbon concentrations and $\mathrm{C} / \mathrm{N}$ values observed over the upper $698 \mathrm{~m}$ of Site 603 (Meyers, this volume) is similar to decreases reported by Waples and Sloan (1980) in Neogene sediments from DSDP Leg 58 in the western North Pacific. They attribute these downhole decreases to continued, postburial microbial degradation of organic matter, with preferential losses occurring to carbon rather than to nitrogen. Such microbial activity would result in the evolu- 


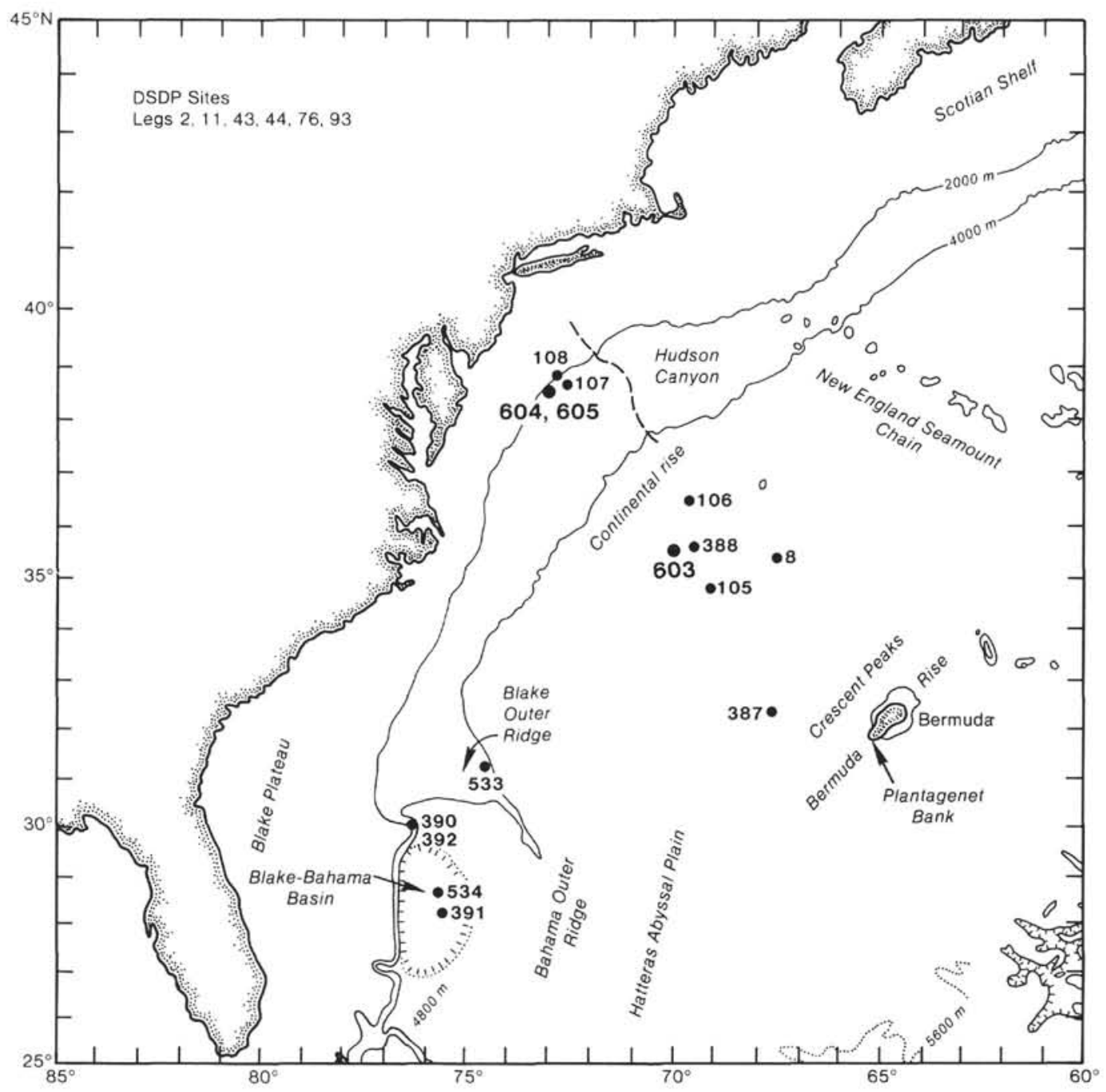

Figure 1. Locations of Sites 603, 604, and 605 and earlier DSDP sites (from Legs 2, 11, 43, 44, 76, and 93) in the western North Atlantic Ocean.

tion of gases, which were indeed abundant in Hole 603 and $603 \mathrm{C}$ cores (Site 603 chapter, this volume); these gases are concluded to be microbial in origin by Whelan and Burton (this volume) on the basis of high methaneto-ethane ratios and low interstitial sulfate concentrations.

In Subunit IC (Fig. 2), concentrations of organic carbon and atomic $\mathrm{C} / \mathrm{N}$ ratios are similar to those present in Subunit IA and are generally higher than those from Subunit IB. These higher values are contrary to what would be expected from continued diagenetic alteration of material deposited under uniform conditions; hence, they signal some sort of change in the paleoceanographic setting. Because biogenic silica also increases in Subunit IC, it is possible that marine productivity was greater during this period of sediment deposition than at more recent times. In support of this interpretation, Emeis et al. (this volume) note a maximum in marine-derived sugars that coincides with the increases in opal, organic carbon, and $\mathrm{C} / \mathrm{N}$ values in this subunit.

In samples below the base of Subunit IC at $950 \mathrm{~m}$ sub-bottom, the extremely low organic carbon values in- dicate little input of organic matter from either marine or continental sources and deposition under oxygenated conditions, resulting in poor preservation of organic matter.

Rock-Eval analyses indicate much of the organic matter throughout Unit I is Type III, terrigenous material (Rullkötter et al., Schaefer and Leythaeuser, Meyers, all this volume). Recycled and oxidized vitrinites with relatively high reflectance values are common (Rullkötter et al., this volume) as a result of incorporation of continental material in these Blake Ridge sediments. The presence of such material may explain unexpectedly high $T_{\max }$ values in some samples of these otherwise thermally immature deposits (Meyers, this volume). The presence of admixed marine organic matter is obvious from the dominance of sugars derived from plankton cell walls in the carbohydrate contents of Unit I sediments (Emeis et al., this volume).

Distributions of extractable lipid materials are consistent with the predominance of terrigenous organic matter. Long-chain, plant wax $n$-alkanes are abundant in hydrocarbon extracts (Emeis et al., Rullkötter et al., this 


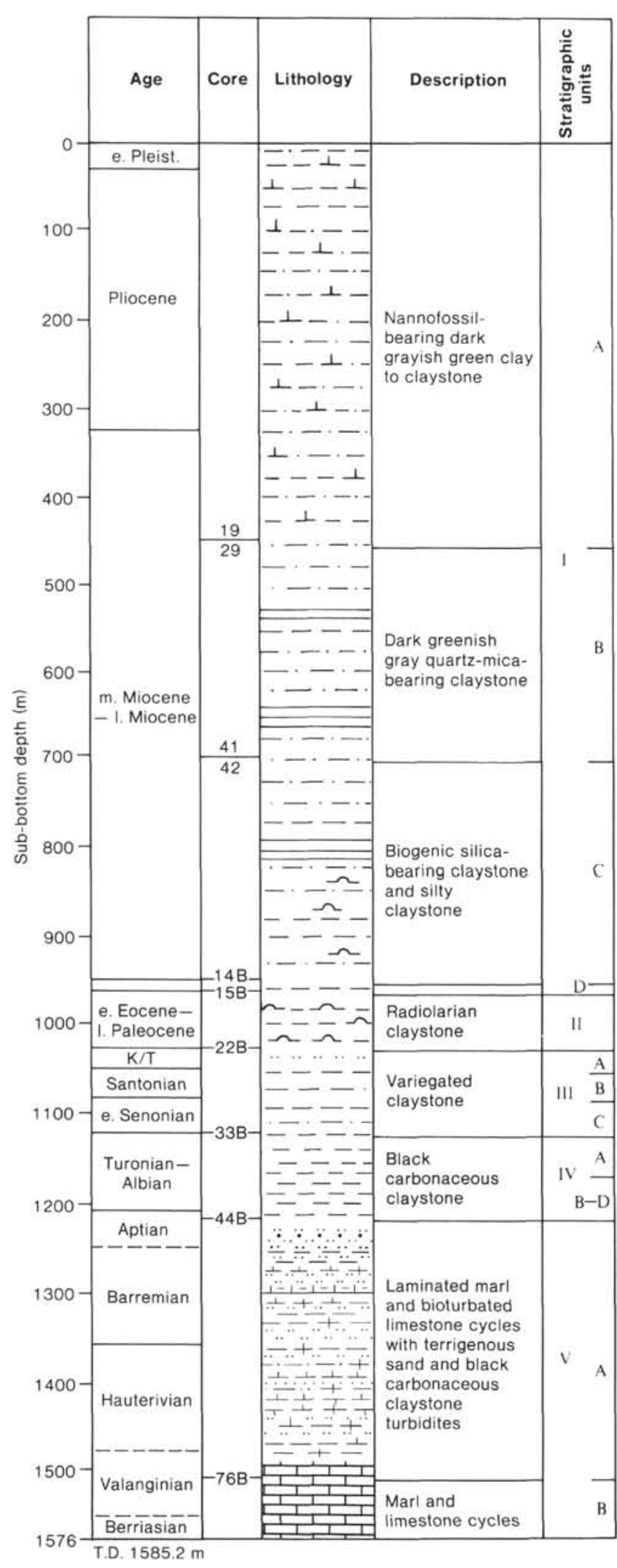

Figure 2. Stratigraphic summary of Site 603 on the outer Hatteras Rise. volume). Marine contributions are indicated by distributions of sterenes The presence of these olefins suggests their rapid incorporation into the sediments, since these compounds are sensitive to oxidation (Rullkötter et al., this volume).

\section{Unit II: Bermuda Rise Formation (Eocene)}

Organic matter concentrations are very low throughout this unit. Shipboard analyses of organic carbon consistently show less than $0.1 \%$ (Meyers, this volume), although the single sample studied by Emeis et al. (this volume) contains $0.13 \%$ organic carbon. Like most of the samples analyzed by these workers, the sugar content is dominated by plankton cell-wall components. A period hostile to accumulation of organic matter in the sediments at this location is indicated by these data.

\section{Unit III: Plantagenet Formation (Turonian to Maestrichtian)}

Concentrations of organic carbon are generally very low throughout this unit, except in the occasional layers of "black shale" in which values up to $8.48 \%$ are found (Rullkötter et al., this volume). Rock-Eval analyses of claystones poor in organic carbon give low hydrogen index values, suggestive of reworked, detrital continental organic matter (Herbin et al.; Katz; Schaefer and Leythaeuser; Cunningham and Gilbert, this volume). Visual examinations of the organic matter content of these samples support this conclusion. Rullkötter et al. (this volume) find $80 \%$ of the kerogen of a claystone sample to consist of recycled vitrinite; Habib and Drugg (this volume) report the dominance of micrinitic, terrigenous organic matter; Cunningham and Gilbert (this volume) determine that $80 \%$ of the kerogen in a silty claystone having an organic carbon content of $1.78 \%$ is terrigenous in origin.

In Sample 603B-32-1, 26-28 cm, a black shale containing $8.48 \%$ organic carbon, Rullkötter et al. (this volume) find a large contribution of marine $n$-alkanes. This sample has a hydrogen index of 346 , characteristic of mixed Type II/III organic matter. A similar hydrocarbon distribution was found in Sample 603B-29-1, 57-62 $\mathrm{cm}$ by Herbin et al. (this volume), although this sample has a hydrogen index of only 34 . The variability in organic matter character in this unit is further shown by the dominance of land-plant $n$-alkanes in Sample 603B29-1, 48-53 cm (Joyce and Van Vleet, this volume), which is not only closely situated to the other Section 603B-291 sample, but also has nearly the same organic carbon content $(1.7$ vs. $1.8 \%)$. This variability is probably a result of the interlayering of turbiditic, hemipelagic, and pelagic sediments in this section.

\section{Unit IV: Hatteras Formation (Aptian to Turonian)}

This unit contains numerous black claystones rich in organic carbon, ranging up to $20.4 \%$ by weight (Herbin et al., this volume). These relatively high organic carbon levels contrast with those of adjacent green and red claystones, which are quite low $(<0.1 \%$, Meyers, this volume). Atomic $\mathrm{C} / \mathrm{N}$ ratios of the black claystones average 33 , whereas the values of interbedded organic-car- 
Table 1. Inferred sources of organic matter in sediments from lithostratigraphic units encountered in Holes 603 and $603 \mathrm{~B}$ on the outer Hatteras Rise. $^{\mathrm{a}}$

\begin{tabular}{|c|c|c|c|c|c|c|c|c|c|}
\hline \multirow[b]{2}{*}{ Unit } & \multirow[b]{2}{*}{ Formation } & \multirow[b]{2}{*}{ Lithology } & \multirow{2}{*}{$\begin{array}{l}\text { Sub-bottom } \\
\text { depth(m) }\end{array}$} & \multirow[b]{2}{*}{$\mathrm{Age}^{\mathrm{b}}$} & \multirow[b]{2}{*}{$\mathrm{C}_{\text {org }}$ Range $(\%)^{\mathrm{C}}$} & \multicolumn{3}{|c|}{ Inferred sources of organic matter } & \multirow{2}{*}{$\begin{array}{c}\text { Reference } \\
\text { (this volume) }\end{array}$} \\
\hline & & & & & & Interstitial gases & Lipids & Kerogen & \\
\hline \multirow[t]{4}{*}{1} & Blake Ridge & $\begin{array}{l}\text { Nannofossil, } \\
\text { opal-rich }\end{array}$ & $\underline{0}$ & $\begin{array}{l}\text { Pleistocene } \\
\text { to }\end{array}$ & 0.01 & \multirow{4}{*}{ Biogenic } & Terrigenous/marine & Marine/terrigenous & Emeis et al. \\
\hline & & clay/claystone & 960 & Eocene & 0.68 & & Terrigenous/marine & Terrigenous/marine & $\begin{array}{l}\text { Rullkötter et al. } \\
\text { Whelan and Burton }\end{array}$ \\
\hline & & & & & & & & Terrigenous/marine & Meyers \\
\hline & & & & & & & & Terrigenous/marine & Schaefer and Leythaeuser \\
\hline \multirow[t]{3}{*}{ II } & Bermuda Rise & Radiolarian- & 960 & Eocene & & & & Marine/terrigenous & Emeis et al. \\
\hline & & bearing & - & & & & & & \\
\hline & & claystone & & & & & & & \\
\hline \multirow[t]{10}{*}{ III } & \multirow[t]{10}{*}{ Plantagenet } & \multirow{10}{*}{$\begin{array}{l}\text { Multicolored } \\
\text { claystones, } \\
\text { with rare } \\
\text { "black shales" }\end{array}$} & \multirow{10}{*}{$\begin{array}{c}1023 \\
- \\
1119\end{array}$} & \multirow{10}{*}{$\begin{array}{c}\text { Maestrichtian } \\
\text { to } \\
\text { late Turonian }\end{array}$} & \multirow{10}{*}{$\begin{array}{l}0.01 \\
- \\
1.95\end{array}$} & \multirow{10}{*}{ Biogenic } & \multirow{6}{*}{ Marine/terrigenous } & \multirow[t]{2}{*}{ Terrigenous/marine } & \multirow{10}{*}{$\begin{array}{l}\text { Whelan and Burton } \\
\text { Schaefer and Leythaeuser }\end{array}$} \\
\hline & & & & & & & & & \\
\hline & & & & & & & & Marine/terrigenous & \\
\hline & & & & & & & & Terrigenous/marine & \\
\hline & & & & & & & & Terrigenous/marine & \\
\hline & & & & & & & & Terrigenous/marine & \\
\hline & & & & & & & \multirow[t]{2}{*}{ Terrigenous/marine } & Terrigenous/marine & \\
\hline & & & & & & & & Terrigenous/marine & \\
\hline & & & & & & & \multirow[t]{2}{*}{ Marine/terrigenous } & Terrigenous/marine & \\
\hline & & & & & & & & Terrigenous/marine & \\
\hline \multirow[t]{11}{*}{ IV } & Hatteras & Green and & 1119 & Turonian & 0.01 & & Terrigenous/marine & Marine/terrigenous & Emeis et al. \\
\hline & & red claystones & - & to & - & & & & \\
\hline & & with "black & 1215 & Aptian & 13.59 & & Terrigenous/marine & Marine/terrigenous & Rullkötter et al. \\
\hline & & & & & & & & Marine/terrigenous & Katz \\
\hline & & & & & & & & Marine/terrigenous & $\begin{array}{l}\text { Meyers } \\
\text { Hahib }\end{array}$ \\
\hline & & & & & & & & $\begin{array}{l}\text { Marine/terrigenous } \\
\text { Terrigenous/marine }\end{array}$ & $\begin{array}{l}\text { Habib and Drugg } \\
\text { Dean and Arthur }\end{array}$ \\
\hline & & & & & & & Terrigenous/marine & Marine/terrigenous & Dunham et al. \\
\hline & & & & & & & & Marine/terrigenous & Cunningham and Gilbert \\
\hline & & & & & & & Terrigenous/marine & Terrigenous/marine & Joyce and Van Vleet \\
\hline & & & & & & & Marine/terrigenous & Marine/terrigenous & Herbin et al. \\
\hline & & & & & & Biogenic & & Marine/terrigenous & $\begin{array}{l}\text { Whelan and Burton } \\
\text { Schaefer and Leythaeuser }\end{array}$ \\
\hline $\mathrm{v}$ & Blake-Bahama & Marlstone, & 1215 & Barremian & 0.01 & & Terrigenous/marine & Marine/terrigenous & Emeis et al. \\
\hline & & sandstone, and & - & to & - & & & & \\
\hline & & claystone & 1576 & Berriasian & 2.57 & & Terrigenous/marine & Terrigenous/marine & Rullkötter et al. \\
\hline & & & & & & & & Terrigenous/marine & Katz \\
\hline & & & & & & & & Terrigenous/marine & Dean and Arthur \\
\hline & & & & & & & & Terrigenous/marine & Habib and Drugg \\
\hline & & & & & & & Terrigenous/marine & Terrigenous/marine & Dunham et al. \\
\hline & & & & & & & & Terrigenous/marine & Cunningham and Gilbert \\
\hline & & & & & & Thermogenic & Terrigenous/marine & $\overline{\text { Terrigenous/marine }}$ & $\begin{array}{l}\text { Herbin et al. } \\
\text { Whelan and Burton }\end{array}$ \\
\hline & & & & & & & & Terrigenous/marine & Schaefer and Leythaeuser \\
\hline & & & & & & & & Terrigenous/marine & Meyers \\
\hline
\end{tabular}

\footnotetext{
a Dominant source appears first where mixed sources are evident and is underlined when it is predominant.

From Habib and Drugg (this volume).

From Meyers (this volume).
}

bon-lean strata average about 12 (Meyers this volume). Similar contrasts in organic carbon contents and $\mathrm{C} / \mathrm{N}$ ratios have been observed in Cenomanian black shales and adjacent green claystones from DSDP Site 530 in the Angola Basin and have been interpreted as preservational effects (Meyers, et al., 1984). Highest organic carbon values are concentrated in Cenomanian claystones, and these are significantly higher than most previously reported values from the Hatteras Formation (cf. Erdman and Schorno, 1978; Deroo et al., 1980; Summerhayes and Masran, 1983), which have $10.4 \%$ as a maximum.

Rock-Eval data from Unit IV samples show a wide range of hydrogen index values (Fig. 3). The Cenomanian black shale samples from the Hatteras Formation generally have high hydrogen indices (Dean and Arthur; Herbin et al., Katz; Meyers; Rullkötter et al.; Schaefer and Leythaeuser; all this volume), representative of marine Type II kerogen. Although most previous studies have concluded that the majority of the organic matter within western North Atlantic Cretaceous black shales is from continental sources, Summerhayes and Masran (1983) suggest that samples with higher organic carbon concentrations contain proportionately larger amounts of marine organic matter. Moreover, some Cenomanian sediments from Site 105 are unusually rich in marine organic matter (Summerhayes, 1981), and Albian-Aptian sediments from Sites 417 and 418 are dominated by marine material (Deroo et al., 1980). The abundance of marine organic matter in those Cenomanian sediments rich in organic carbon at Hole 603B evidently represents short episodes of enhanced preservation of marine material superimposed upon a low background of terrigenous organic matter. Samples from other parts of Unit IV contain poorly preserved, or nonmarine, organic matter.

Carbon isotope ratios are reported for organic carbon contained within the black shales and adjacent strata of the Hatteras Formation. In Cenomanian black shales, Joyce and Van Vleet (this volume) and Dunham et al. (this volume) find a general positive correlation between organic carbon content and the heavier $\delta^{13} \mathrm{C}$ values typical of modern marine organic matter. The isotope signature in other examples of Cretaceous black shales is often reversed, however, with marine organic matter hav- 


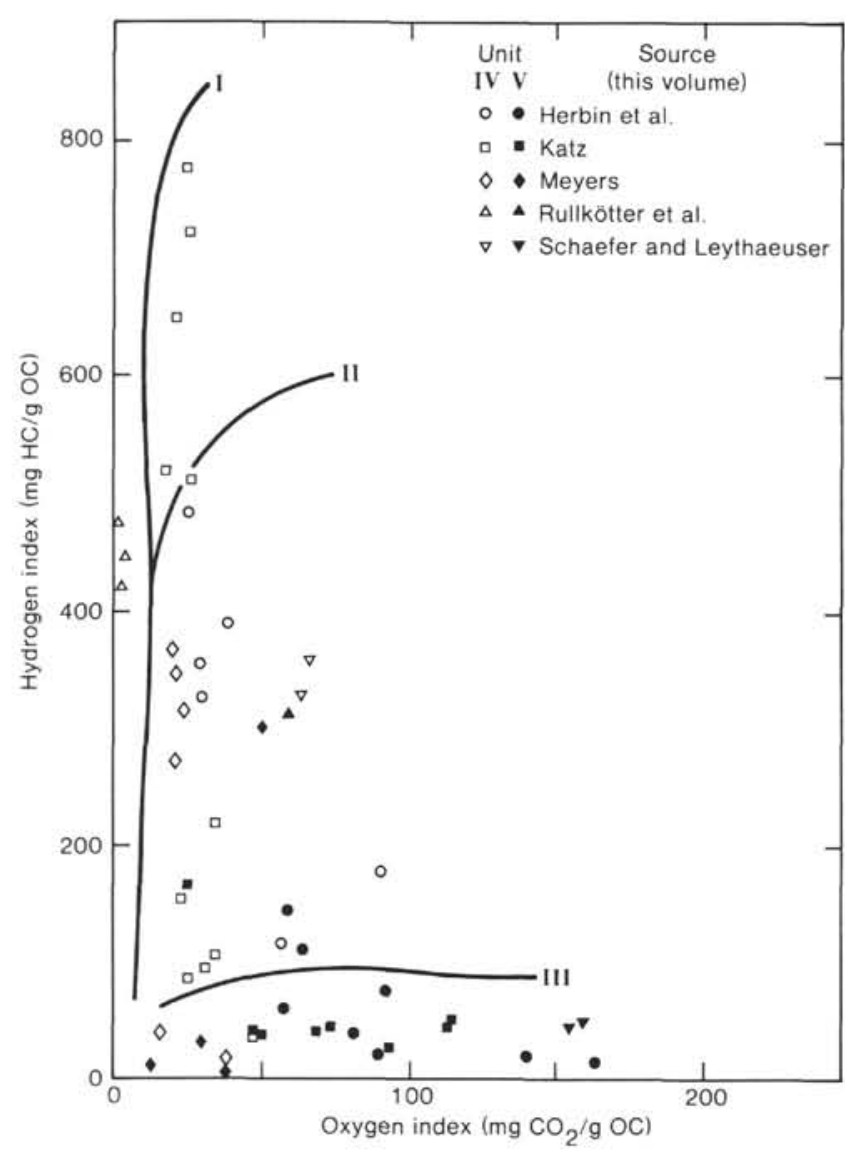

Figure 3. Summary of Rock-Eval analyses of samples from Unit IV (Hatteras Formation) and Unit V (Blake-Bahama Formation) at Site 603. Hydrogen index is given in milligrams hydrocarbon per gram organic carbon, and oxygen index is expressed as milligrams $\mathrm{CO}_{2}$ per gram organic carbon.

ing $-\delta^{13} \mathrm{C}$ values of -27 to $-29 \%$ and continental values being less depleted in ${ }^{13} \mathrm{C}$ (Meyers et al., 1984; Arthur et al., 1985; Dean et al., 1986). Carbon isotope analyses from a large suite of Hatteras Formation samples by Dean and Arthur (this volume) indicate that marine organic matter is indeed isotopically lighter than in modern sediments. In fact, the highest Rock-Eval hydrogen indices, which are indicative of marine organic matter, are recorded in Cenomanian black shales that are also the isotopically lightest. Other black shales, as well as the green and red claystones, appear to contain lesser proportions of marine organic matter. Considerable variability in Rock Eval and isotope values from adjacent samples from this unit probably result from the changes in organic matter input and preservation associated with turbiditic deposition at this site.

In contrast to the predominantly marine character of kerogen in Unit IV black shales, the lipid materials are generally dominated by plant wax, terrigenous components. Both the extractable and bound fractions of $n$-alkanes, $n$-alkanoic acids, and $n$-alkanols contain major contributions of long-chain, biogenic components (Herbin et al.; Emeis et al.; Dunham et al.; Joyce and Van Vleet; Rullkötter et al., this volume). Lipid contents comprise a lower proportion of the total organic matter in black shales than in adjacent red or green claystones (Dunham et al., this volume), where land-plant components are often minor. This difference in lipid richness is also inferred by Dean and Arthur (this volume) from Rock-Eval hydrogen indices and suggests that the organic matter in the black shales may have been redeposited from basin margin locations in an oxygenated, deepbasin site as a result of turbidity flow.

Exceptions to the general dominance of continental lipid components are found in upper Cenomanian black shales. In these deposits, from Cores 603B-33 and 34, hydrocarbon distributions indicate large proportions of marine lipid material (Herbin et al.; Rullkötter et al., this volume). Pristane/phytane ratios less than one in these Cenomanian/Turonian samples lead Herbin et al. (this volume) to suggest anoxic deposition, but Dean and Arthur (this volume) and Katz (this volume) conclude that the sulfur contents of these samples are not high enough to indicate bottom-water anoxia, and Bonnell and Anderson (this volume) find that $\delta^{34} \mathrm{~S}$ values of disseminated pyrite are similar to those of modern oxic marine sediments.

Concentrations of $\mathrm{C}_{2}$ to $\mathrm{C}_{8}$ hydrocarbons are relatively low and reflect the thermal immaturity of the Hatteras Formation rocks at Site 603 (Schaefer and Leythaeuser, this volume). From the dominance of methane over other light hydrocarbons, Whelan and Burton (this volume) assign a biogenic origin to the interstitial gases . Low thermal maturity of the organic matter is further indicated by vitrinite data (Rullkötter et al.; Emeis et al., this volume) and by visual kerogen descriptions (Cunningham and Gilbert; Habib and Drugg, this volume).

\section{Unit V: Blake-Bahama Formation (Berriasian to Barremian)}

The organic carbon contents of the various sedimentary types in Unit V do not differ greatly. The highest reported value is $3.14 \%$ (Dunham et al., this volume) for a black marlstone. The mean organic carbon concentration calculated from 33 such marlstones is $1.47 \%$ (Meyers, this volume). In comparison, the mean value for laminated limestones is about $1 \%$ and for bioturbated limestones it is about $0.2 \%$ (Meyers; Dean and Arthur, this volume). Shipboard scientists observed that atomic $\mathrm{C} / \mathrm{N}$ ratios of organic matter increased in Blake-Bahama sediments at the same time that the amount of coaly particles increased markedly, indicating inputs of continental plant debris in the submarine fan sequence at Site 603.

As summarized in Figure 3, Rock-Eval data show most of the organic matter to be oxidized, Type III material in this unit (Katz; Dean and Arthur; Herbin et al.; Schaefer and Leythaeuser; all this volume). Several samples of turbiditic black marlstones, relatively rich in organic carbon, contained Type II kerogen (Meyers, this volume), but such examples are not typical of this sequence. Relatively low $T_{\max }$ values in the range of 400 to $430^{\circ} \mathrm{C}$ show low thermal maturity in these sediments (Katz; Meyers; Dean and Arthur; Herbin et al.; Schaefer and Leythaeuser; this volume), which agrees with visual maceral analyses (Rullkötter et al.; Cunningham 
and Gilbert; Habib and Drugg; all this volume) and low bitumen yields (Katz, this volume).

Like the organic carbon concentrations, the carbon isotope compositions of organic matter are relatively uniform in Unit $\mathrm{V}$. The mean $\delta^{13} \mathrm{C}$ values of black shales, laminated limestones, and bioturbated limestones are $-25.3,-26.0$, and $-25.0 \%$, respectively (Dean and Arthur, this volume), and the isotopically light black shales found in the Hatteras Formation at this site are not present in the Neocomian sections obtained during Leg 93. Mostly recycled, land-derived material constitutes the bulk of the organic matter throughout Blake-Bahama sediments at Site 603 , although components of algal cell walls continue to dominate the carbohydrate compositions of these sediments (Emeis et al., this volume).

Consistent with the largely terrigenous character of bulk organic matter, lipid distributions in black shales and limestones from the Blake-Bahama Formation contain large contributions from land plant waxes (Herbin et al.; Rullkötter et al.; Emeis et al.; Dunham et al.; all this volume). Non-aromatic hydrocarbon compositions are dominated by $\mathrm{C}_{27}, \mathrm{C}_{29}$, and $\mathrm{C}_{31} n$-alkanes, with some samples having bimodal distributions in which $\mathrm{C}_{17}$ and $\mathrm{C}_{19} n$-alkanes also appear prominently. Pristane/phytane ratios in black shales are usually greater than one, suggesting oxygenated depositional conditions (Didyk et al., 1978) or limited methanogenic activity (Risatti et al., 1984).

Humic and vitrinitic organic matter is especially abundant in the Neocomian sediments obtained at Site 603 (Cunningham and Gilbert; Habib and Drugg; Rullkötter et al.; this volume). Shipboard scientists commonly observed coaly particles in smear slides (Site 603 chapter, this volume), which Habib and Drugg (this volume) postulate may originate from in situ partial oxidation of buried land-derived plant debris. Rullkötter et al. (this volume) report the existence of a relatively well preserved piece of humic coal containing framboidal pyrite in a Barremian sample. They conclude that short-distance transport from a coastal swamp to this continental rise location and rapid reburial within a turbidite sequence is the most reasonable explanation for this interesting finding.

An exception to the general terrigenous origin of the organic matter content of Site 603 Blake-Bahama sediments occurs in Valanginian deposits in Subunit VB. Turbidites are uncommon in this subunit, and pelagic carbonates are the dominant lithologic type. Organic matter in this subunit appears to be mostly aquatic in origin, consisting largely of zooplankton fecal pellets, although it is structurally degraded and partially oxidized (Habib and Drugg; Ru11kötter et al., this volume).

Analysis of $\mathrm{C}_{2}$ to $\mathrm{C}_{8}$ hydrocarbons suggests that some small-scale migration of lighter components has occurred from black shale layers into organic-lean strata (Schaefer and Leythaeuser, Whelan and Burton, this volume). From distributions of these interstitial hydrocarbons, Whelan and Burton (this volume) conclude they may be at least partially thermogenic in origin. Low concentra- tions of these light hydrocarbons, however, reflect the general lack of thermal maturation in this section.

\section{Factors Contributing to Deposition of Black Shales at Site 603}

Both the type and the amount of organic matter contained within black shales and their adjacent strata provide information about the paleoceanographic processes that participated in the formation of Cretaceous black shales in the western North Atlantic Ocean. Possible explanations of black shale depositional conditions are exemplified by de Graciansky et al. (1982), Summerhayes and Masran (1983), and Summerhayes (in press) and combine the effects of sea-level changes, changes in continental climates, nutrient availability, and basin morphology to achieve periods of midwater or bottom anoxia in the Mesozoic North Atlantic. It is probable that these are the important factors, but de Graciansky et al. (1984) caution that a simple model employing one set of conditions appears inadequate to explain the geographically broad extent of Cenomanian black shales. Similar caution may be appropriate in seeking explanations of black shale formation in other parts of the geological record as well.

The proportion of continental and marine organic matter present in black shale samples from the western North Atlantic varies considerably. Although most of the organic matter appears to be terrigenous (Katz and Pheifer, 1982), the marine fraction increases with distance from North America (Tissot et al., 1980; Summerhayes and Masran, 1983). This pattern has been explained by Summerhayes and Masran (1983) to reflect the decrease in turbiditic dilution of marine sediments with continental materials as distance from shore increases. Exceptions to this generality occur where large proportions of marine organic matter are found in Cenomanian black shales at Site 105 (Summerhayes, 1981) and in Cenomanian and Valanginian black shales at Site 603 . Both sites are located on the continental rise and in turbiditic environments. These exceptions illustrate the regional and temporal variability that can exist in the mixture of organic matter types in black shales.

Preservation of organic matter is an important element in forming organic-carbon-rich black shales. Anoxic bottom waters have been postulated to have enabled enhanced preservation of organic matter in the Cretaceous North Atlantic (Tissot et al., 1980; Arthur and Schlanger, 1979; Jenkyns, 1980; Summerhayes and Masran, 1983; Bralower and Thierstein, 1984; as examples). The abundant presence of burrowed, oxidized sediments above, below, and sometimes within the black shales in this ocean argues against such bottom water anoxia being extensive in either volume or duration (Katz and Pheifer, 1982; Waples, 1983). Nonetheless, the high concentrations of organic carbon found in Cenomanian black shales over most of the North Atlantic Ocean are compelling evidence in favor of periods of widespread bottom water anoxia. As noted by Herbin et al. (this volume), the Cenomanian-Turonian black shale sequence 
at Site 603 consists of 19 episodes of exceptional preservation of marine organic matter within a 9-m thickness of sediment. They propose short periods of bottom anoxia to achieve the observed alternations between black shales and green claystones.

Another scenario leading to enhanced preservation of organic matter calls for the midwater oxygen minimum zone to become intensified and perhaps expanded through sluggish circulation or enhanced influx of organic matter (e.g., Demaison and Moore, 1980; Waples, 1983). Where a midwater anoxic layer intercepts the ocean bottom, sediments rich in organic matter can accumulate. Downslope movement of such sediments can result in formation of black shales within deep-ocean turbiditic sequences, as suggested by Dean et al. (1984) for Site 530 in the Angola Basin, if reburial is sufficiently rapid to preserve the organic matter. This scenario points out another factor important to preservation of organic materials - the sedimentation rate. From a survey of DSDP data, Ibach (1982) shows that organic matter degradation is depressed as a function of sediment accumulation rates in Mesozoic sediments. Quicker burial results in better preservation, even under oxygenated bottomwater conditions, through establishment of anoxic conditions in the sediments whenever organic matter supplies are sufficient to deplete pore-water oxygen levels. This phenomenon has led Habib (1983) and Robertson and Bliefnick (1983) to suggest that Mesozoic black shales at Site 534 result primarily from rapid sedimentation of terrigenous organic matter associated with turbidity currents and that the western North Atlantic need not have been anoxic during these episodes. In view of the abundance of turbidites at Site 603 and the generally terrigenous character of organic matter in sediments from both the Hatteras and Blake-Bahama Formulations, Rullkötter et al., Habib and Drugg, and Katz (all this volume) conclude that downslope displacement and rapid reburial by turbidity flows created the black shale deposits at this continental rise location.

The high biological productivity associated with upwelling produces elevated concentrations of organic matter in underlying ocean margin sediments (e.g., Demaison and Moore, 1980), and Parrish and Curtis (1982) noted a correspondence between postulated paleo-upwelling areas and occurrence of Cretaceous black shales. Nonetheless, the overall productivity of the western North Atlantic was probably low to moderate, on the basis of sediment compositions (Waples, 1983; de Graciansky et al., 1984; Bralower and Thierstein, 1984). Indeed, Demaison and Moore (1980) comment on the lack of correlation in modern oceans between productivity and preservation of marine organic matter. In general, conditions in the water column and at the sea bottom seem to be the major elements in black shale formation in the western North Atlantic through preservation, and not production, of organic matter, with the possible exception of Cenomanian and Valanginian times when the influx of marine material was enhanced.

A factor that can markedly influence the concentrations of organic carbon found in marine sediments is the degree of dissolution of the sediment fraction com- posed of calcium carbonate. In general, black shales having the highest concentrations of organic carbon have been deposited below the calcite compensation depth (CCD), thus concentrating noncarbonate components. Part of the difference found in organic carbon contents of Hatteras Formation black shales and those of the Blake-Bahama Formation (actually marlstones) at Site 603 is from carbonate dilution of organic matter in the Neocomian strata.

The paleoceanographic picture that emerges is that the Cretaceous western North Atlantic appears (1) to have been a small sea filled with oxygenated water, (2) to have received an abundant supply of terrigenous clastics, and (3) to have had at best moderate levels of marine productivity. How did black shales form under such conditions? Although it is possible that bottom-water anoxia existed from time to time in the basins comprising the proto-At1antic, it is unlikely that enough marine organic matter would survive sinking through the predominantly oxygenated water column to form black shales. It is more likely that the organic material reached the deep-ocean sites of black shale deposition in the company of turbidity flows, and preservation occurred from rapid burial in the oxygenated deep basins.

This scenario of downslope transport and redeposition is essentially the same as earlier proposed by Dean and Gardner (1982) for Site 367 in the Cape Verde Basin, by Dean et al. (1984) for Site 530 in the Angola Basin, and by Robertson and Bliefnick (1983) for Site 534 in the Blake-Bahama Basin. Also, this scenario helps explain the variability in organic character present in the sediments of the western North Atlantic. This explanation is based upon assuming each occurrence of black shale deposition to be a local or regional event, loosely linked to other such events by paleoceanographic conditions. Changes in climate, sea level, or oceanic circulation might destabilize ocean margin sediments and initiate turbidity flows at numerous locations around the North Atlantic. Such flows need not be synchronous and need not contain the same organic matter content. Except for those originating where the oxygen minimum layer intercepts the bottom, most would actually be poor in organic carbon; all would have their proportions of marine and terrigenous materials controlled by local conditions. On the seafloor, these flows would form fanlike deposits that would overlap and interfinger, rarely creating the continuous black shale layers like those formed under shallow epicontinental seas. Although each black shale deposit would be initiated by a common set of global or oceanwide conditions, individual characteristics would be determined by regional or local factors.

\section{SITES 604 AND 605: UPPER NEW JERSEY RISE}

Drilling of two holes at Site 604 (2328 m water depth) and one at Site 605 (2194 m) (Fig. 1) provided a detailed record of sedimentation and sediment transport processes on the upper continental rise off New Jersey dating back to the late Maestrichtian. Figure 4 presents the lithologic units found at these sites. The Site 604 and 605 chapters (this volume) give details of these units, and only their brief descriptions are given here. 

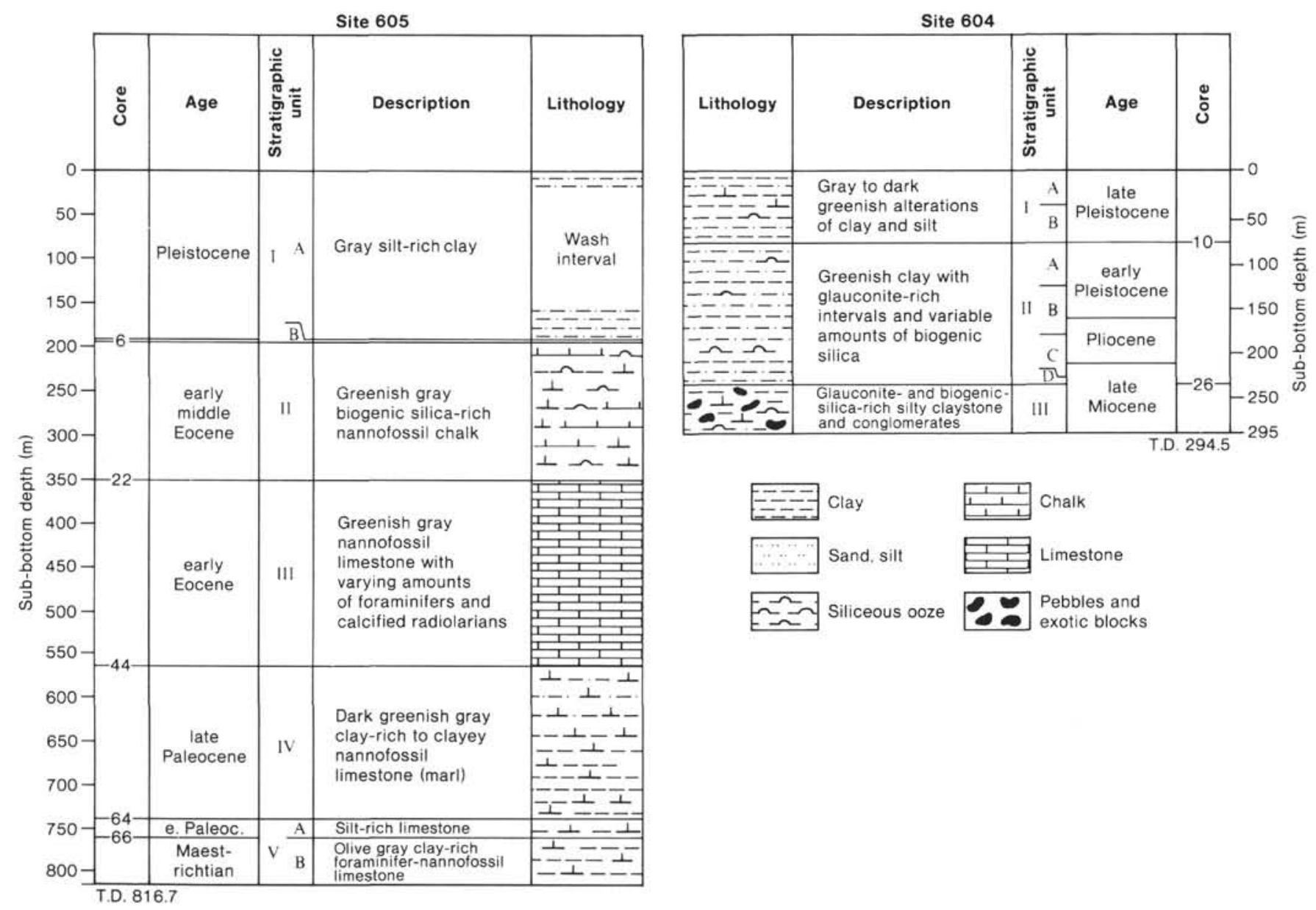

Figure 4. Stratigraphic summaries of Sites 604 and 605 on the New Jersey continental slope.

In Site 604 sediments, organic carbon concentrations range from essentially nil to $2.1 \%$ and bear no relationship to lithologic units. Atomic $\mathrm{C} / \mathrm{N}$ values are similarly quite variable (Meyers, this volume). These variabilities suggest a dynamic depositional environment, where the proportions of marine and terrigenous components of organic matter have fluctuated and the amount of clastic dilution has varied, in this ocean margin setting. In general, conditions appear not to have favored preservation of organic matter, although detailed geochemical analyses of these sediments were not done to verify this inference.

Organic carbon concentrations are low in sediments from Site 605 . The average value is $0.22 \%$, and the highest percentage is only $0.60 \%$ (Meyers, this volume). Atomic $\mathrm{C} / \mathrm{N}$ ratios are high for marine sediments, averaging about 25, which is characteristic of continental organic matter (Müller, 1977; Premuzic et al., 1982). Considerable variability in both organic carbon concentrations and $\mathrm{C} / \mathrm{N}$ ratios suggests fluctuations in the inputs of marine and terrigenous organic matter to these sediments.

One sedimentary process that has probably been important in influencing the character of organic matter in these ocean margin sediments is slumping. Tarafa et al. (in press) compare the pyrolysis products obtained from slumped and non-slumped Eocene sediments from Units
II and III. They conclude that organic matter in slumped sediments is better preserved than in nonslumped sediments, probably because of more rapid and deeper burial and consequent protection from burrowing infauna.

An excellent example of the Cretaceous/Tertiary (K/T) boundary was encountered at Site 605 . According to dinoflagellate stratigraphy, the boundary occurs between 64 and $78 \mathrm{~cm}$ in Section 605-66-1 and closely resembles the micropaleontological record in Stevns Klint, Denmark (Habib and Drugg, this volume). A geochemical comparison of samples from above and below the boundary from Site 605 and from Denmark is made by Simoneit and Beller (this volume). They find that $n$-alkane distributions suggest important contributions of land-plant waxes to the Site 605 sediments below the $\mathrm{K} / \mathrm{T}$ boundary Above the boundary, these contributions diminish. Pristane/phytane ratios are greater than one in Maestrichtian sediments and less than one in the overlying Danian carbonates. These data may reflect a change from oxic to anoxic conditions across the $\mathrm{K} / \mathrm{T}$ boundary (Didyk et al., 1978) or an increase in the activity of methanogenic bacteria in the Danian sediments (Risatti et al., 1984). In contrast to the changes in geolipid character found at Site 605, the Stevns Klint samples show little difference above and below the boundary. Evidence of microbial reworking of sedimentary organic matter is 
strong, and this reworking may have obliterated any differences in the original character of sedimentary organic matter.

\section{SUMMARY AND CONCLUSIONS}

Cenozoic sediments contain low amounts of organic matter at Site 603 on the outer Hatteras Rise, reflecting accumulation in a well-oxygenated, bioturbated depositional environment.

Aptian to Turonian sediments contain numerous, thin layers of dark-colored claystones interspersed among red and green claystones within a generally turbiditic, bioturbated lithologic sequence. The "black shales" contain elevated concentrations of organic carbon, although not as high as found in similar deposits in the eastern North Atlantic, whereas the red and green claystones contain virtually no organic matter.

Neocomian strata display many thin, black marlstones deposited as turbidites within a sequence of pelagic bioturbated and laminated carbonates. Organic carbon concentrations of both the dark marlstones and the limestones are on the order of 1 to $2 \%$, which is less than values of the Aptian to Turonian black shales deposited below the calcite compensation depth.

Terrigenous organic matter dominates most sediments both enriched and lean in organic carbon at Site 603 on the outer continental rise. Transport from the North American continent probably cecurred mostly by turbidity flow. The terrigenous organic matter is relatively lipid poor.

Marine organic matter is found in sediments deposited immediately prior to the Cenomanian/Turonian boundary and during Valanginian times. Concentrations of organic carbon reach $20 \%$ in Cenomanian black shales but are only a few percent in Valanginian marlstones. The dominance of marine organic matter may indicate enhanced aquatic productivity during these two intervals or it may record major changes in the degree of preservation of marine matter. Although deep-basin anoxia would achieve better preservation, the abundance of oxidized sediment components and of faunal burrowing rules against widespread, long-term anoxia in the western proto-Atlantic Ocean. A scenario of basin-margin deposition within an oxygen-minimum zone and downslope transport and reburial by turbidity flows seems more likely to have formed the "black shales" at Site 603.

Organic matter is thermally immature throughout these sections, although small amounts of light hydrocarbons appear to have been generated from Neocomian black marlstones.

Cenozoic sediments from Sites 604 and 605 on the New Jersey continental slope have variable contents of organic matter, reflecting a history of slumping and downslope redeposition within an oxygenated environment. Slumping may enhance preservation through rapid burial of organic matter.

Geolipid distributions in sediments above and below the we11-defined Cretaceous/Tertiary boundary at Site 605 indicate a decrease in liand-plant contributions from Maestrichtian to Danian times at this location.

\section{ACKNOWLEDGMENTS}

1 thank the authors who sent me copies of their manuscripts and Elizabeth Whalen, of the DSDP staff, for her help in preparing this synthesis. I especially appreciate the very helpful comments of Keith A. Kvenvolden, who reviewed this paper.

\section{REFERENCES}

Arthur, M. A., Dean, W. A., and Claypool, G. E., 1985. Anomalous ${ }^{13} \mathrm{C}$ enrichment in modern marine organic carbon. Nature, 35: 216-218.

Arthur, M. A., and Schlanger, S. O., 1979. Cretaceous "oceanic anoxic events" as causal factors in development of reef-reservoired giant oil fields. Am. Assoc. Pet. Geol. Bull., 63:870-885.

Bralower, T. J., and Thierstein, H. R., 1984. Low productivity and slow deep-water circulation in mid-Cretaceous oceans. Geology, 12:614-618.

Dean, W. E., Arthur, M. A., and Claypool, G. E., 1986. Depletion of ${ }^{13} \mathrm{C}$ in Cretaceous marine organic matter: source, diagenetic, or environmental signal? Mar. Geol., 70:119-157.

Dean, W. E., Arthur, M. A., and Stow, D. A. V., 1984. Origin and geochemistry of Cretaceous deep-sea black shales and multicolored claystones, with emphasis on Deep Sea Drilling Project Site 530, southern Angola Basin. In Hay, W. W., Sibuet, J. C. et al., Init. Repts. DSDP, 75, Pt. 2: Washington (U.S. Govt. Printing Office), 819-844.

Dean, W. E., and Gardner, J. V., 1982. Origin and geochemistry of redox cycles of Jurassic to Eocene age, Cape Verde Basin (DSDP Site 367), continental margin of northwest Africa. In Schlanger, S. O., and Cita, M. B., (Eds.) Nature and Origin of Cretaceous Carbonrich Facies: London (Academic Press), pp. 55-78.

Demaison, G. J., and Moore, G. T., 1980. Anoxic environments and oil source bed genesis. Org. Geochem., 2:9-31.

Deroo, G., Herbin, J. P., Roucaché, J., and Tissot, B., 1980. Organic geochemistry of Cretaceous sediments at DSDP Holes 417D (Leg 51), 418A (Leg 52), and 418B (Leg 53) in the western North Atlantic. In Donnelly, T., Francheteau, J., Bryan, W., Robinson, P., Flower, M., Salisbury, M., et al., Init. Repts. DSDP, 51, 52, 53, Pt. 2: Washington (U.S. Govt. Printing Office), 737-745.

Didyk, B. M., Simoneit, B. R. T., Brassell, S. C., and Eglinton, G., 1978. Geochemical indicators of paleoenvironmental conditions of sedimentation. Nature, 272:216-222.

Erdman, J. G., and Schorno, K. S., 1978. Geochemistry of carbon: Deep Sea Drilling Project Leg 44. In Benson, W. E., Sheridan, R. E., et al., Init. Repts. DSDP, 44: Washington (U.S. Govt. Printing Office), 605-615.

Graciansky, P. D. de, Brosse, E., Deroo, G., Herbin, J.-P., Montadert, L., Müller, C., Sigal, J., and Schaaf, A., 1982. Les formations d'age Cretacé de L'Atlantique Nord et leur matière organique: paleogéographie et milieux de dépot. Rev. Inst. Fran. Pet., 37/3:275-337.

Graciansky, P. C. de, Deroo, G., Herbin, J. P., Montadert, L., Müller, C., Schaff, A., and Sigal, J., 1984. Ocean-wide stagnation episode in the Late Cretaceous. Nature, 308:346-349.

Habib, D., 1983. Sedimentation-rate-dependent distribution of organic matter in the North Atlantic Jurassic-Cretaceous. In Sheridan, R. E., Gradstein, F. M., et al., Init. Repts. DSDP, 76: Washington (U.S. Govt. Printing Office), 781-794.

Ibach, L. E. J., 1982. Relationship between sedimentation rate and total organic carbon content in ancient marine sediments. Am. Assoc. Pet. Geol. Bull., 66:170-188.

Jansa, L. F., Enos, P., Tucholke, B. E., Gradstein, F. M., and Sheridan, R. E., 1979. Mesozoic-Cenozoic sedimentary formations of the North American Basin, Western North Atlantic. In Talwani, M., Hay, W., and Ryan, W. B. F. (Eds.), Deep Drilling Results in the Atlantic Ocean: Continental Margins and Paleoenvironment: Washington (Am. Geophys. Union), pp. 1-57.

Jenkyns, H. D., 1980. Cretaceous anoxic events: from continents to oceans. J. Geol. Soc. London, 137:171-188.

Katz, B. J., and Pheifer, R. N., 1982. Characteristics of Cretaceous organic matter in the Atlantic. In Watkins, J., and Drake, C. (Eds.), Geology of Continental Margins. Am. Assoc. Pet. Geol. Mem., $34: 617-628$ 


\section{P. A. MEYERS}

Meyers, P. A., Leenheer, M. J., Kawka, O. E., and Trull, T. W., 1984. Enhanced preservation of marine-derived organic matter in Cenomanian black shales from the southern Angola Basin. Nature, 312: 356-359.

Müller, P. J., 1977. C/N ratios in Pacific deep-sea sediments: effect of inorganic ammonium and organic nitrogen compounds absorbed by clays. Geochim, Cosmochim. Acta, 41:765-776.

Parrish, J. T., and Curtis, R. L., 1982. Atmospheric circulation, upwelling and organic-rich rocks in the Mesozoic and Cenozoic eras. Paleogeogr., Paleoclimatol., Paleoecol., 40:31-66.

Premuzic, E. T., Benkovitz, C. M., Gaffney, J. S., and Walsh, J. J., 1982. The nature and distribution of organic matter in the surface sediments of world oceans and seas. Org. Geochem., 4:63-77.

Risatti, J. B., Rowland, S. J., Yon, D., and Maxwell, J. R., 1984. Stereochemical studies of acyclic isoprenoids-XII. Lipids of methanogenic bacteria and possible contributions to sediments. Org. Geochem., 6:93-104.

Robertson, A. H. F., and Bliefnick, D. M., 1983. Sedimentology and origin of Lower Cretaceous pelagic carbonates and redeposited clastics, Blake-Bahama Formation, Deep Sea Drilling Project Site 534, western equatorial Atlantic. In Sheridan, R. D., Gradstein, F. M., et al., Init. Repts. DSDP, 76: Washington (U.S. Govt. Printing Office), 795-828.

Summerhayes, C. P., 1981. Organic facies of middle Cretaceous black shales in the deep North Atlantic. Am. Assoc. Pet. Geol. Bull., 65: 2364-2380. in press. Organic rich Cretaceous sediments from the North Atlantic. In Brooks, J., and Fleet, A. J. (Eds.), Marine Petroleum Source Rocks: Oxford (Blackwells).

Summerhayes, C. P., and Masran, T. C. 1983. Organic facies of Cretaceous and Jurassic sediments from Deep Sea Drilling Project Site 534 in the Blake-Bahama Basin, western North Atlantic. In Sheridan, R. E., Gradstein, F. M., et al., Init. Repts. DSDP, 76: Washington (U.S. Govt. Printing Office), 469-480.

Tarafa, M. E., Whelan, J. K., and Mountain, G. S., in press. Sediment slumps during the middle and early Eocene of DSDP Holes 605 and $613-$ Chemical detection via pyrolysis techniques. In Poag, C. W., Watts, A. B., et al., Init. Repts. DSDP, 95: Washington (U.S. Govt. Printing Office).

Tissot, B. P., Demaison, G., Masson, P., Deteil, J. R., and Combaz, A., 1980. Paleoenvironment and petroleum potential of the midCretaceous black shales in the Atlantic basins. Am. Assoc. Pet. Geol. Bull., 64:2051-2063.

Waples, D. W., 1983. Reappraisal of anoxia and organic richness, with emphasis on Cretaceous of North Atlantic. Am. Assoc. Pet. Geol, Bull., 67:963-978.

Waples, D. W., and Sloan, J. R., 1980. Carbon and nitrogen diagenesis in deep sea sediments. Geochim. Cosmochim. Acta., 44:14631470.

Date of Initial Receipt: 19 August 1985

Date of Acceptance: 31 January 1986 